\title{
EMS-45 Tool Steels Hardenability Experiment using Jominy ASTM A255 Test Method
}

\author{
Syamsul Hadi ${ }^{1}$, Eddy Widiyono ${ }^{1}$, Winarto ${ }^{1}$, and Dedy Z. Noor ${ }^{1}$
}

\begin{abstract}
Hardenability of steels is an important way to determine heat treatment and material properties that produce component products. Jominy test is one of the method to know hardenability of steels. The Jominy ASTM A255 in used as a method for carriying out and this reseach. Parameter such as austenite temperature, holding time, cooling rate and then the results is dedicated by the prediction result, with Non Linear Numerical Equation Method. Based on test, it's known, increasing austenite temperature, longer holding time and high cooling rate, will increase hardenability of steels. The different between the results and the prediction result done by Sonh Yue-Peng ${ }^{[15]}$, Matja equation ${ }^{[14]}$ and Zehtab equation ${ }^{[10]}$, about $5 \%-10 \%$. The data obtained from this experiment can be used to determine the appropriated heat treatment in order to get the desired mechanical properties, as well as to avoid distortion.
\end{abstract}

Keywords — Jominy, heat treatment, tool steels, distortion, hardenability

Abstrak-Hardenability baja merupakan petunjuk penting untuk menentukan pola laku panas dan sifat bahan yang akan dilakukan dalam menghasilkan produk komponen. Salah satu cara untuk mengetahui hardenability baja, yaitu dengan menggunakan metode uji jominy. Penelitian ini, menggunakan metode uji jominy ASTM A255, dengan parameter temperatur austenisasi, waktu penahanan, media pendingin, kemudian diverifikasikan dengan hasil prediksi menggunakan metode persamaan numerik tidak linear. Berdasarkan hasil penelitian diperoleh, bahwa makin tinggi temperatur austenisasi dan makin lama waktu penahanan, nilai kekerasan akan semakin meningkat. Sedangkan untuk baja dengan laju pendiginan cepat kekerasannya lebih tinggi dibanding dengan baja pendinginan lambat. Perbedaan data hasil uji dan hasil prediksi yang dilakukan oleh Sonh Yue-Peng ${ }^{[5]}$, persamaan Matja ${ }^{[14]}$, dan persamaan Zehtab ${ }^{[10]}$, sekitar $5 \%-10 \%$. Data dari hasil penelitian ini, dapat digunakan dalam penentuan laku panas yang sesuai dengan sifat mekanik yang diinginkan dan untuk menghindari terjadinya distorsi.

Kata Kunci— Jominy, laku panas, baja perkakas, distorsi, hardenability

\section{INTRODUCTION}

$\mathrm{H}$ ardenability of steels is a mechanical property which describes the ability to form martensite on a quenching process to achieve a certain hardness at a given depth. Hardenability is used to know hardness improvement during a hardening process when a rapid cooling is taken places on austenite region $[1,2]$.

Hardenability of steels can be taken as consideration in order to chose a heat treatment process or to product a component. One of the techniques in testing harrdenability of steels is jominy test [3]. Jominy test ASTM A255 is one of the cheapest and effective method for hardenability test. This method can be developed as an alternative way in deriving Continuous Cooling Transformation (CCT) diagram [4-6].

Hardenability depends on heat treatment and chemical composition and it is used as comparison in heat treatment process to get hardness or microstructure of steel. In the other word, Jominy curve can be used to predict desired hardness distribution of hardened steel with different dimension and cooling medium [7-9].

Some studies have been made regarding mathematical model of transition phase of eutektoid carbon steel. The studies furthermore were developed into numerical models to simulate jominy test which can be used to predict thermal cycles to derive CCT diagram [10-13]. Jominy test can be modified by using computer

${ }^{1}$ Syamsul Hadi, Eddy Widiyono, Winarto, and Dedy Z. Noor are with Department of Mechanical Engineering Diploma 3 Program, FTI, Institut Teknologi Sepuluh Nopember, Surabaya, 60111, Indonesia. Email:syamsul@me.its.ac.id,eddy_w@me.its.ac.id,winarto@me.its.ac.id , and zulnoor@me.its.ac.id. simulation in such a way that cooling rate of heat treatment is used to predict hardenability of cold work tool steels [10, 14-15].

Hardness values on several points of a jominy speciment can be predicted using Quench Factor Analysis (QFA) method i.e. the combination of cooling curve and hardness test results [16], while the modification of the jominy test (JMC-test) method is used as predicted jominy test results by combining cooling curve with various cooling medium which is very usefull in determining hardenability of tool steels [17]. The neural network method based on chemical composition can be applied to predict herdenability of steels as well [18].

Hardenability can be applied as one method to anticipate distorsion due to rapid cooling using Coooling Rate Band (CRB) method [19].

There are many hardenability tests for steel done by previous reseachers, but there is no special hardenability test for EMS-45 steel. The present work is carried out in order to study the effect of heat treatment on hardenability of tool steel EMS 45 using Jominy ASTM A255 testing method. It is desired that the current research can be used to select heat treatment in achieving desirable mechanical properties to avoid distorsion.

\section{TESTING PROCEDURE}

\section{A. Tested Material}

The material which is used in this work is ashaft from stell EMS-45 with the composition as Table 1.

\section{B. The Dimention}

The speciments is formed according to the ASTM A255 Jominy standard dimension as shown in Figure 1. 


\section{Heat Treatment}

The speciments are treated using the variation of austenation temperature, holding time and cooling rate as tabulated in Table 2 .

\section{Metallurgical Test}

Metallurgical test is carried out by 500 times magnification [20]. Metallography test procedure is described in Figure 2. EMS 45 Steel is etched by nital and observed by Olympus microscope with magnification 500x.

\section{E. Hardenability Test}

Rockwell method was applied for hardness test equipment in the present work using ASTM E18 standard [21]. Hardness test was conducted by rockwell method with scale C. Specimen surface was polished and tested for every $5 \mathrm{~mm}$ distance.

\section{RESULTS AND DISCUSSION}

The Jominy test is functioned to measure hardenability of a stell because it transforms from austenite to martensite either in whole or part of it, as shown in Figure 3.

Figure 5 shows the hardenability of EMS-45 stell after it is treated at temperatur $900^{\circ} \mathrm{C}$ with the holding time 40 minute using the Jominy test. The maximum hardness is achieved at the tip of the specimen with micro structure martensite and value of 59 HRC. This hardness decreases and the micro structure is changed from martensite to pearlite when the distance is farther from the tip as the result of slower cooling. The minimum hardness is found to be $10 \mathrm{HRC}$ with the micro structure of rough pearlite.

In a slow cooling, austenite phase transformed into ferrite and pearlite. This transformation occurs because of diffusion that takes time and temperature, while the martensite transformation does not occur due to diffusion of atoms, but due to the thrust that goes very fast. Martensite is a metastable structure in the form of supersaturated solid solution in which the carbon trapped in the structure of the BCT (Body Center Tetragonal). Hardening capacity describes the most hard surfaces that can be achieved by rapid cooling process (quenching). It can be achieved if there is $100 \%$ martensite in the microstructure.

\section{A. Heating Temperature Effect}

Carbon content can raise the hardness of a steel because it can resist the formation of ferrite-pearlite phase thereby accelerating the formation of martensite on the slow cooling rate but can not increase the hardenability. Whereas a high austenization temperature greatly influences hardness and hardenability of steel.

A higher austenization temperature enlarges the grain size of austenite. It will affect transformation of austenite transformation and the transformation curve moves to the right in the transformation diagram. For the same cooling rate, more martensite will be formed for a larger grain size.

Before having Jominy test, the speciments have been given the heat treatment with the holding time 40 minutes and the temperature variation of $900^{\circ} \mathrm{C}, 860^{\circ} \mathrm{C}$, and $830^{\circ} \mathrm{C}$. Based on the Jominy test, the hardness values of the speciments were same at the tip as shown in Figure 6. The hardness decreased for the location far from the tip. The different hardness was shown clearly at the distance $25 \mathrm{~mm}$ from the tip. At this distance the hardness values for the temperature variation of $900^{\circ} \mathrm{C}$, $860^{\circ} \mathrm{C}$ and $830^{\circ} \mathrm{C}$ were $48 \mathrm{HRC}, 35 \mathrm{HRC}$ and $22 \mathrm{HRC}$, respectively. The higher temperature gave more capability for austenite grain to grow in size and atom diffusion occured properly until homogen contition was reached. Furthermore the speciments were cooled rapidly, so that appear residual stress, and microstructure changes occured from austenite to martensite which affected hardenability of steel.

\section{B. Holding Time Effect}

Nucleation of ferrite and pearlite occur on the heterogen locations like grain boundaries. The more time holding increses austenite grain and decreases the locations for nucleation so that the transformation from ferrite to pearlite is blocked. In order to get a high hardenability of steel, substantially, the larger austenite grain is needed by giving more holding time and then quenching (rapid cooling).

Figure 7 shows the hardenability curve for EMS-45 steel which has been treated at $900^{\circ} \mathrm{C}$ with different holding time. Judging from the curve, the maximum and minimum hardness for each speciment are found at the base and the tip i.e. $59 \mathrm{HRC}$ and $10 \mathrm{HRC}$, respectively. For the longer holding time, the hardness was found greater at the position between $5 \mathrm{~mm}$ to $60 \mathrm{~cm}$ from the base. Phase transformation occurs during heat treatment when there was enough holding time. when austenite temperature was reached, austenite phase was formed. The formed austenite grain still had small size, furthermore a longer holding time gave opportunity for austenite grain to grow and atoms to difuse in order to form it more homogen. A higher hardness value was reached after hardening and treating with longer holding time.

Figure 8 shows the metallurgical test of EMS-45 steel for different holding time at temperature $900^{\circ} \mathrm{C}$ and distance $5 \mathrm{~mm}$ from cooling tip. The micro structure was found as martensite and bainite.

The tip dan base had the same hardness values of 59 HRC and $10 \mathrm{HRC}$, respectively, for different treatments. The differences were found at diastance $5 \mathrm{~mm}$ from the tip. The heat treatments using 20 minutes, 30 minute and 40 minutes holding time had 55.7 HRC with $80 \%$ martensite, $57.1 \mathrm{HRC}$ with $82 \%$ martensite and 58.3 HRC with $85 \%$ martensite, respectively.

\section{Cooling Media Effect}

Cooling rate strongly influences hardness of a steel. To get a fully martensite micro structure, the cooling rate have to reach the Critical Cooling Rate (CCR). If cooling rate is less than CCR, austenite will not transform into martensite, instead it will change to be the other structure (bainite or pearlite) in such a way that a maximum hardness is not achieved.

It can be observed from Figure 9 that the highest and the lowest hardness were found when water and air were used as cooling medium, respectively. Water had higher coefficient of convection than air, therefore it gave more heat transfer or cooling rater than air. Furthermore, a 
rapid cooling due to a higher cooling rate supported the formation of martensite with the high hardness.

\section{Verification of Hardenability Data}

The experiment result for austenisation temperature and holding time of $900^{\circ} \mathrm{C}$ and 40 minutes, respectively, are compared with the theoretical and numerical models $[6,14,18]$ as shown in Figure 10.

There was no significant different between the test result with the prediction results especially at the base and the tip. The difference only about $5 \%$ to $10 \%$.

\section{E. Avoiding Distorsion}

The hardenability curve can be devided into four hardness area and microstructures which are related to distorsion due to a rapid cooling.

Figure 11 reveals the different microstructure and hardness as follows:

- Area I had 85-100\% martensite with high hardness and distortion as a result of a high rapid cooling.

- Area II was formed by a rapid cooling with 59-85\% martensite. It had high and homogen hardness with low distortion.

- Area III was occopied by bainite and pearlite microstructures, it was formed through a slow cooling rate resulting non homogen and low hardness as well as low distortion.

- Area IV was formed by slowest cooling ferrit and pearlit microstructures, it was not happened hardness and very small distortion.

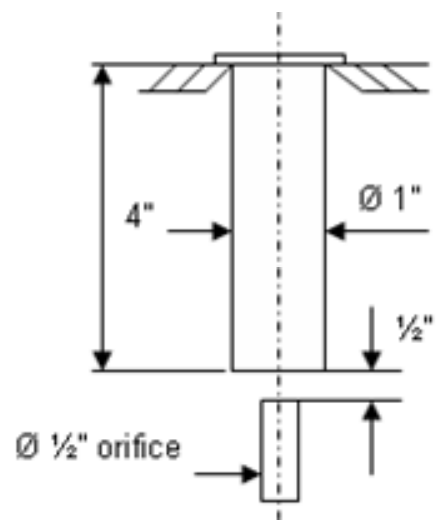

Figure 1. The Dimension of the Jominy Tested Material

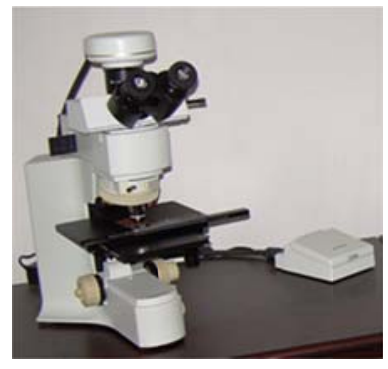

Figure 3. Olympus microscope

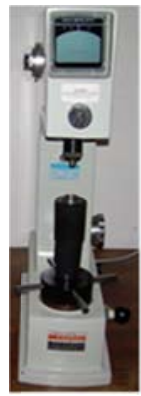

In order to avoid distortion, There is special heat treatment for EMS-45 steel. The heat treatment is carried out for austenisation temperature and holding time of $900^{\circ} \mathrm{C}$ and 40 minutes, respectively, using mixture of water and oil as cooling media. the test result is obtained about $58 \mathrm{HRC}$ and distorsion is not found.

\section{CONCLUSION}

Based on the testing results on EMS-45 steel using Jonimy method, some conclusions can be derived as follows:

1. The maximum hardness was found on the cooling tip with the micro structure martensite. This hardness value decreases and the microstructure changed into pearlite due to slow cooling when the distance away from the cooling tip.

2. The highest hardenability for Jominy test on EMS-45 steel was achieved at austenitation temperature and holding time of $900^{\circ} \mathrm{C}$ and 40 minutes, respectively.

3. Austenitation temperature and holding time did not give significant effect on the tip and the base cooling.

4. The highest hardness and the most rapid cooling was achieved using water while the lowest hardness and the slowest cooling was gained using air as the medium.

5. The difference between the test results with predicted results was not significant.

6. Jominy test data can be used as a reference in the heat treatment process for hardening tool steel, as an effort to obtain adequate mechanical properties and avoid distortion.

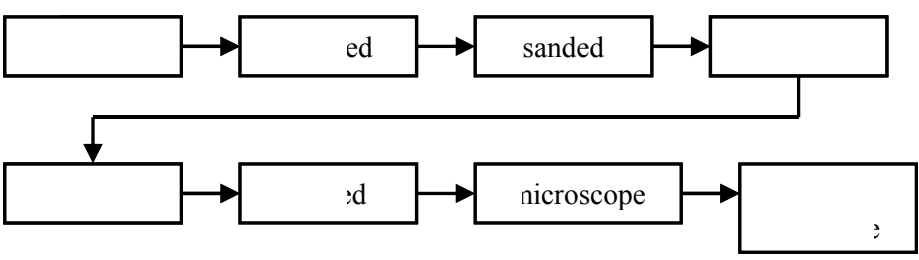

Figure 2. Metallography test procedure

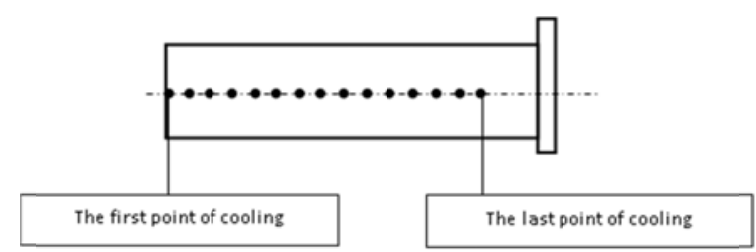

Figure 4. Hardness test equipment and the locations of material testing on the speciment 


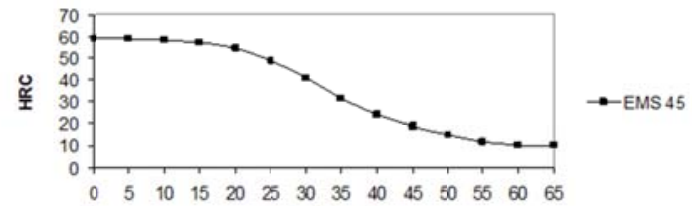

Figure 5. Hardenability curve and micro structure of EMS-45 stell with temperature $900^{\circ} \mathrm{C}$ and holding tim 40 minute

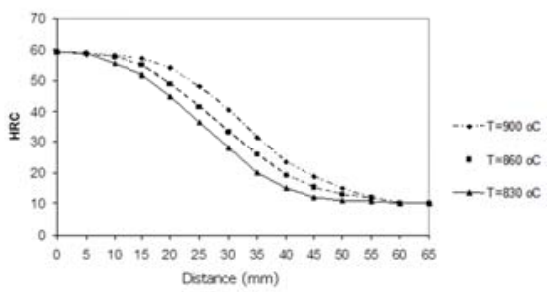

Figure 6. Hardenability curve of EMS-45 steel temperature variation and holding time 40 minute

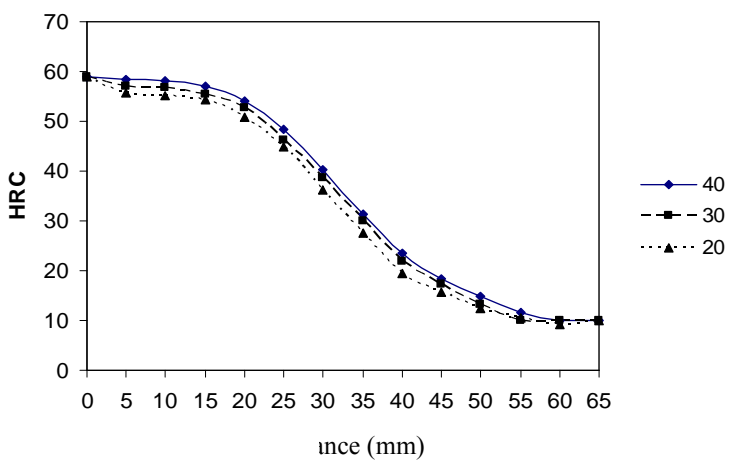

Figure 7. Hardenability curve of EMS-45 for temperature of $900^{\circ} \mathrm{C}$ with different holding time i.e. 20, 30 , and 40 minutes.

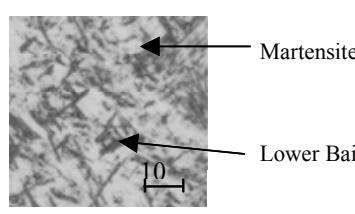

(a)

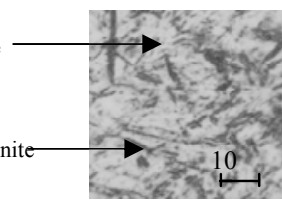

(b)

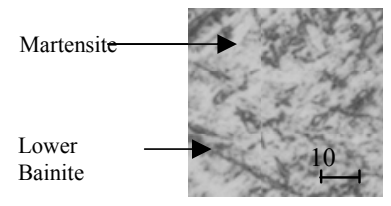

(c)

Figure 8. Micro structure of EMS-45 at temperature $900^{\circ} \mathrm{C}$ and diffrent holding time (a) 20 minutes, (b) 30 minutes, (c) 40 minutes
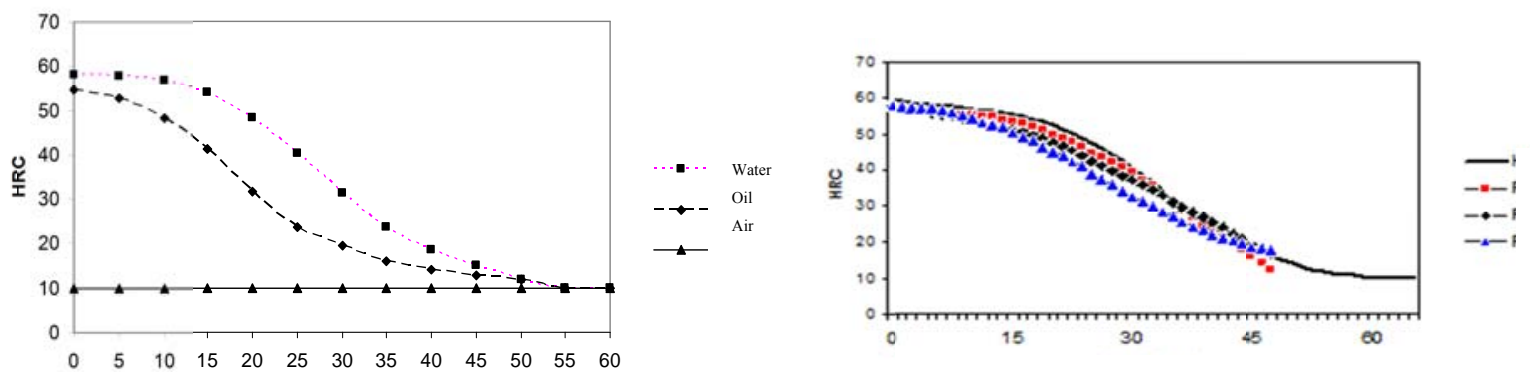

Figure 9. Hardenability curve of EMS-45 steel at temperature $900^{\circ} \mathrm{C}$ and holding time 40 minutes with variation of cooling medium i.e. water, oil and air.
Figure 10. Comparison of hardenability curve of EMS-45 steel and the predictions. 


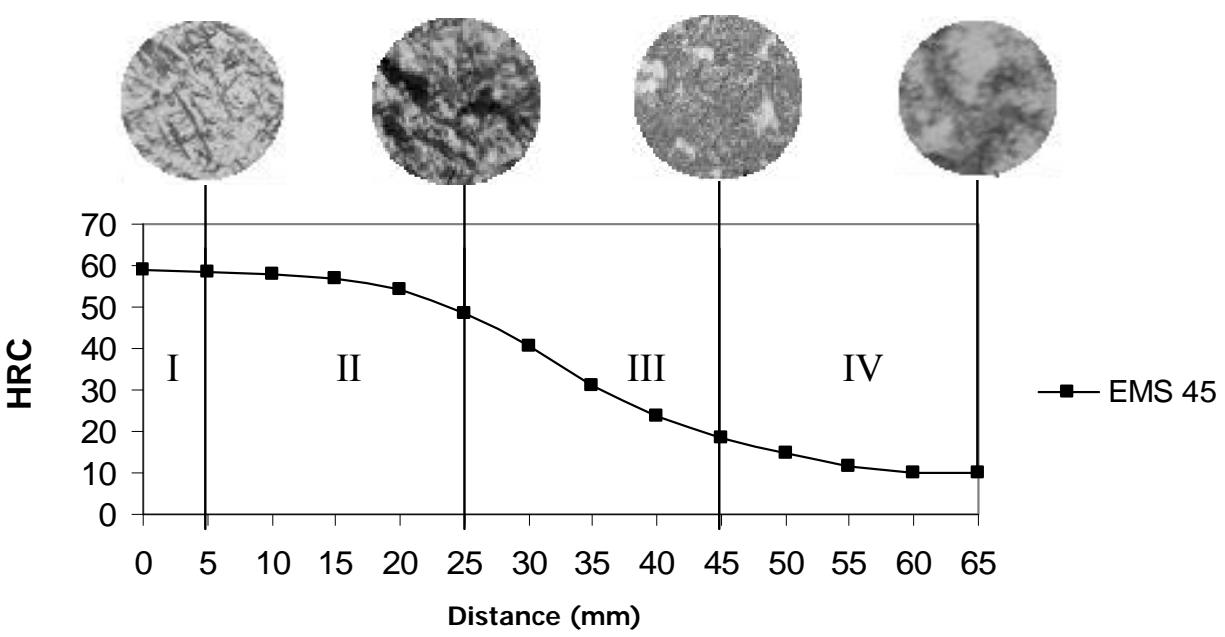

Gambar 11. Hardenability curve of EMS-45 steel for testing at temperature of $900^{\circ} \mathrm{C}$ and holding time 40 minutes

TABLE 1.

THE COMPOSITION

\begin{tabular}{ccccccccc}
\hline Material & $\mathrm{C}$ & $\mathrm{Si}$ & $\mathrm{Mn}$ & $\mathrm{P}$ & $\mathrm{S}$ & $\mathrm{Cr}$ & $\mathrm{Ni}$ & $\mathrm{Cu}$ \\
\hline \multirow{2}{*}{ EMS 45 } & $0,47 \%$ & $0,28 \%$ & $0,77 \%$ & $0,01 \%$ & $0,07 \%$ & $0,03 \%$ & $0,01 \%$ & $0,02 \%$ \\
\hline
\end{tabular}

TABLE 2.

HEAT TREATMENT OF SPECIMENT

\begin{tabular}{lcccc}
\hline Material & Austenite temperature $(\mathrm{T})$ & Holding time $(\mathrm{t})$ & Cooling media (sprayed) & Sum of speciment \\
\hline EMS-45 & $900{ }^{\circ} \mathrm{C}$ & 40 minutes & Water & 3 speciments \\
EMS-45 & $900{ }^{\circ} \mathrm{C}$ & 30 minutes & Water & 3 speciments \\
EMS-45 & $900{ }^{\circ} \mathrm{C}$ & 20 minutes & Water & 3 speciments \\
EMS-45 & $860^{\circ} \mathrm{C}$ & 40 minutes & Water & 3 speciments \\
EMS-45 & $830{ }^{\circ} \mathrm{C}$ & 40 minutes & Water & 3 speciments \\
EMS-45 & $900{ }^{\circ} \mathrm{C}$ & 40 minutes & Oil & 3 speciments \\
EMS-45 & $900{ }^{\circ} \mathrm{C}$ & 40 minutes & Air & 3 speciments \\
\hline
\end{tabular}

\section{REFERENCES}

[1] ASTM A370. Standard Test Methods and Definitions for Mechanical Testing of Steel Products. American Society for Testing and Materials, 1997.

[2] W.D. Callister, Materials Science and Engineering, 6 edition, Jhon Wiley and Sons, New York, 2002.

[3] H.S. Fong, Further Observations on the Jominy End Quench Test, Journal of Materials Peocessing Technology, vol. 38,p. 221-226, 1993.

[4] ASTM A255. (1999). Standard Test Methods for Determining Hardenability of Steel. American Society for Testing and Materials,

[5] C. F. Jatczak, Hardenability of Carbon and Alloy Steels, Metals Handbook, Vol. 1, $9^{\text {th }}$ Edition, ASM International, p. 492.

[6] Mehmet Cakir, Abdullah Ozsoy Investigation of the correlation between thermal properties and hardenability of Jominy bars quenched with air-water mixture for AISI 1050 steel, Journal of Materials and Design, Elsevivier, vol.32 (2011), p.3099-3105.

[7] ASTM E140. Standard Hardness Conversion Tables for Metals, 1997.

[8] ASM Handbook, Vol. 4, Heat Treating - Heat Treating of Steel. American Society for Metals, 1991.

[9] T. Karl-Erik, Steel and its Heat Treatment, Butterworths, p 145, 1975.

[10] A. Zehtab Yazdi, S.A. Sajjadi, S.M. Zebarjad, S.M. Moosavi Nezhad, Prediction of hardness at different points of Jominy specimen using quench factor analysis, method, journal of materials processing technology, Elsevivier, vol 199, p. 124-129 B.L, 2008 .

[11] D. Homberg. "A Numerical Simulation of The Jominy End-Quench Test", Weierstrass Institut for Applied Analysis and Stochastics, Mohrenstra Be 39, D-10117 Berlin, Germany, 1996.

[12] P. L. Masson, T. Loulou, E. Artioukhine, D. Carron, A Numerical Study for The Estimation of Convection Heat Transfer Coefficient During a Metallurgical Jominy End Quench Test. International Journal of Thermal Siences, vol. 41, 517-527, 2002.

[13] B. Smoljan, D. Rubesa, N. Tomasic, D. Iljic, S. Hanza, An Application of Modified Jominy Test in Computer Simulation of Quenching of Cold Work Tool Steels. $1^{\text {st }}$ International Coference of Heat Treament and Surface Engineering of Tools and Dies, Pula, Croatia, 2005.

[14] Matja ž Knap , J. Falkus , A. Rozman, J. Lamut, Hardenability prediction based on chemical composition of steel, Materials and Geoenvironment, Vol. 56, No. 2, pp. 108-117, 2009.

[15] S.Yue-peng, L. Guo-quanl, L. Sheng-xin, L. Jian-tao, F. Cheng-ming Improved Nonlinear Equation Method for Numerical Prediction of Jominy End-Quench Curves, Sciencedirect, Journal Of Iron And Steel Research, International. 2007,vol 14 no. 1, pp. 37-41, 2007.

[16] Z.A.Yahdi, Sajjadi, S.A., Zerbajad S.M., Nezhad Moosavi, Prediction of Hardness different points of Jominy Specimen Using Quench Factor Analysis Method. Journal of Materials Processing Technology, Elsevivier, vol.199, p.124-129, 2008. 
[17] B. Smoljan, D. Iljic, S. Hanza, T. Traven, An Analysis of Modified Jominy Test (JMC®-test), Computational Materials Sicences and Surface Engineering, vol.2, p.120-124, 2009.

[18] M. Knap, J. Falkus, A. Rozman, J. Lamut, Hardenability Prediction Based on Chemical Composition of Steel. Material and Geoenvironment, Vol. 56, No.2, p.108-117, 2009.

[19] Zhang Ke-Jian Reduction and Elimination of Quench Distortion by CRB Method, Beijing HuaLi Fine Chemical Company Ltd. Beijing 102200, China, 2007.
[20] Bramfitt and S. J. Lawrence, Metallography and Microstructures of Carbon and Low-Alloy Steels, Metallography and Microstructures, Vol 9, ASM Handbook, ASM International, 2004, p. 608-626, 2004.

[21] ASTM E18. Standard Test Methods for Rockwell Hardness and Rockwell Superficial Hardness of Metallic Materials. American Society for Testing and Materials, 2000. 